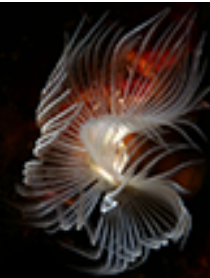

\title{
Determination of the perception of ship management towards environmental pollution caused by routine operations of ships
}

\author{
Osman ARSLAN¹, Murat Selçuk SOLMAZ², Hasan Bora USLUER ${ }^{3}$
}

Cite this article as:

Arslan, O., Solmaz, M.S., Usluer, H.B. (2022). Determination of the perception of ship management towards environmental pollion caused by routine operations of ships. Aquatic Research, 5(1), 39-52. https://doi.org/10.3153/AR22005

${ }^{1}$ Kocaeli University, Maritime Faculty, Maritime Transportation and Management Engineering Department, Kocaeli, Turkey

${ }^{2}$ Piri Reis University, Maritime Faculty, Maritime Transportation and Management Engineering Department, Istanbul, Turkey

${ }^{3}$ Galatasaray University, Maritime

Vocational School, Istanbul, Turkey

ORCID IDs of the author(s):

O.A. 0000-0003-4384-3510

M.S.S. 0000-0002-8528-2865

H.B.U. 0000-0001-8988-9288

Submitted: 23.02 .2021

Revision requested: 11.07 .2021

Last revision received: 02.08 .2021

Accepted: 03.08.2021

Published online: 20.12 .2021

Correspondence:

Osman ARSLAN

E-mail: osmanarslan881@gmail.com

\begin{abstract}
In order to leave a livable world to future generations, the elimination of environmental pollution, which is one of the important dimensions of sustainability, increases its importance every day. Undoubtedly, among the factors that cause environmental pollution, the role of ships is quite high. The seas are also polluted by the routine operation of ships as well as marine accidents. Pollution arising from the routine operations of ships is caused by the discharge of pollutants such as ballast water, bilge water, sludge or garbage into the sea. In addition, emissions from ships and oil and fuel pollution caused by the routine operation of ships also play an important role in environmental pollution. In this study, the phenomena resulting from the routine operations of ships and causing environmental pollution were examined using the Analytical Hierarchy Process (AHP) method, which is one of the multi-criteria decision-making methods, and the perceptions of ship operators towards environmental pollution were tried to be determined.
\end{abstract}

Keywords: Environmental Pollution, Maritime Transportation, Ship Operations, Ship Management, AHP, Perception 


\section{Introduction}

Maritime transportation, which is of great importance in terms of world trade, is a very advantageous mode of transportation compared to other transport modes due to its safe, economical and high carrying capacity. With the development of the world economy and industry, the demand in maritime transportation has increased rapidly, and this has led to an increase in the number and tonnage of ships. The increase in the number and size of the ships leads to an increase in environmental pollution.

The seas, which have been a source of life for people for centuries, have been used as waste disposal areas in recent years. According to the data of the International Maritime Organization (IMO), wastes entering the world's seas; $8 \%$ from natural resources, $0.5 \%$ from offshore production, $11 \%$ from sea transport, 30\% from atmospheric sources, $40 \%$ from flood and land based discharges, $10 \%$ from illegal discharge (Küçük and Topçu, 2012). Ships, which are the main elements of maritime transport, cause sea pollution to a large extent and less air pollution (Satır, 2007). Marine pollution as defined by UN Convention on the Law of the Sea (UNCLOS), Article 1.4 (1982) is: "means the introduction by man, directly or indirectly, of substances or energy into the marine environment, including estuaries, which results or is likely to result in such deleterious effects as harm to living resources and marine life, hazards to human health, hindrance to marine activities, including fishing and other legitimate uses of the sea, impairment of quality for use of sea water and reduction of amenities." Air pollution is the presence of pollutants such as dust, gas, fog, odor, smoke or steam in the atmosphere in quantity, density and time that will harm human, plant and animal life or material objects (Satır, 2007). The maritime sector, which realizes more than 90 percent of the world trade with approximately 90,000 vessels, contributes greatly to environmental pollution and climate change. The enormous increase in maritime transport today also increases ship pollution significantly (URL-1).

Operational pollution means that marine pollution caused by ships is not limited to accidents. Actually, most of the pollutants are released during the voyage of the ship, not by accident (Özdemir et al., 2016). Marine transportation generates negative impacts on the marine environment, including greenhouse gas emissions, air pollution, releases of ballast water containing aquatic invasive species, garbage, historical use of antifoulants, giving directly to the sea of raw sewages, oil and chemical spills, dry bulk cargo releases, resulting of oil and waste water after deck washing operations (Walker et al., 2019; Özdemir et al., 2016). These pollutants are very harmful for marine environment.

Maritime transport makes a large contribution to greenhouse gases and air pollution (Miola and Ciuffo, 2011). Ship emissions compose a major, and so far, poorly regulated, source of air pollution (Jonson et al., 2020). Shipping activity can pollute the atmosphere through routine operations. In particularly, carbon dioxide (CO2), carbon monoxide (CO), sulphur oxide (SOx), nitrogen oxide (NOx) and particulate matter (PM) are released due to the operation of the ship's machinery and the incineration of waste, which contributes to global warming and acid rain (Potters, 2013; Aygül and Baştuğ, 2020). As a result of the burning of fossil fuels used in ship machinery, exhaust emissions are harmful to the environment and human health (Aygül and Baştuğ, 2020).

The most important convention prepared under the leadership of the International Maritime Organization (IMO) regarding ship-related pollution is the International Convention for the Prevention of Pollution from Ships (MARPOL), shortly MARPOL 73/78. This contract, to which many countries are parties, has six annexes (IMO, 2020a).

Annex I: Regulations for the Prevention of Pollution by Oil,

Annex II: Regulations for the Control of Pollution by Noxious Liquid Substances in Bulk,

Annex III: Prevention of Pollution by Harmful Substances Carried by Sea in Packaged Form,

Annex IV: Prevention of Pollution by Sewage from Ships,

Annex V: Prevention of Pollution by Garbage from Ships,

Annex VI: Prevention of Air Pollution from Ships.

When the literature is searched, there are many studies on marine pollution originating from ships. In addition, it was seen that studies were carried out on air pollution caused by ship emissions and their effects on human health. The literature on these subjects was reviewed and studies on environmental pollution caused by ships are given in Table 1 .

In the study, the causes of marine and air pollution caused by the routine operation of ships were examined by reviewing the literature and the indicators found were evaluated by experts such as inspectors, technical directors and designated persons ashore (DPA) working in ship management. The priority levels of the indicators were calculated using the Analytical Hierarchy Process (AHP) method with the data obtained from the experts. 
Table 1. Studies on environmental pollution caused by ships.

\begin{tabular}{|c|c|c|c|}
\hline Author(s) & Aim/Aims & Method/Methods & Results or Conclusions \\
\hline $\begin{array}{l}\text { Baykal and Baykal } \\
\text { (1999) }\end{array}$ & $\begin{array}{l}\text { To provide precautions and } \\
\text { suggestions that can be taken during the } \\
\text { build and operation of ships related to } \\
\text { marine pollution caused by ship-sourced } \\
\text { wastewater. }\end{array}$ & Literature review. & $\begin{array}{l}\text { Issues related to wastewater should } \\
\text { be seriously addressed by planning } \\
\text { in advance, starting from the } \\
\text { project stage of the ships, } \\
\text { including the build and delivery } \\
\text { processes. }\end{array}$ \\
\hline $\begin{array}{l}\text { Saxe and Larsen } \\
(2004)\end{array}$ & $\begin{array}{l}\text { To model the dispersal of } \mathrm{NOx}, \mathrm{SO}_{2} \text { and } \\
\text { primary formed particulate matter } \\
\text { originating from ships in the Danish } \\
\text { harbours. }\end{array}$ & $\begin{array}{l}\text { The operational meteorological air } \\
\text { quality model (OML) was used to } \\
\text { calculate the urban dispersion of air } \\
\text { pollutants originating from ships in } \\
\text { three Danish ports. }\end{array}$ & $\begin{array}{l}\text { It was concluded that emission } \\
\text { from ships in harbour could } \\
\text { possibly induce health problems to } \\
\text { people in the Danish ports. }\end{array}$ \\
\hline Satır (2007) & $\begin{array}{l}\text { To develop a ship waste reception facility } \\
\text { model. }\end{array}$ & $\begin{array}{l}\text { The planning, site selection, } \\
\text { installation and operation of a ship } \\
\text { waste reception facility are examined } \\
\text { together with different alternatives. }\end{array}$ & $\begin{array}{l}\text { The developed model is supported } \\
\text { by scientific data, as is the case } \\
\text { with the site selection of the waste } \\
\text { facility. }\end{array}$ \\
\hline $\begin{array}{l}\text { Iduk and Nitonye } \\
(2015)\end{array}$ & $\begin{array}{l}\text { To find solutions to marine pollution } \\
\text { caused by non-compliance with the } \\
\text { standards set for the protection of the } \\
\text { marine environment. }\end{array}$ & $\begin{array}{l}\text { Questionnaire/descriptive method was } \\
\text { used to find out the effects and solu- } \\
\text { tion of marine pollution from ships. }\end{array}$ & $\begin{array}{l}\text { Sources of marine pollution from } \\
\text { ships have been established, which } \\
\text { included discharge of oily water } \\
\text { from bilge, invasive organisms } \\
\text { from ballast, accidental discharge } \\
\text { of oil from tankers ships and } \\
\text { operational discharge, etc. }\end{array}$ \\
\hline $\begin{array}{l}\text { Zhu and Zhao } \\
(2015)\end{array}$ & $\begin{array}{l}\text { To assess the feasibility of applying the } \\
\text { Polluter-Pays Principle (PPP) to its fullest } \\
\text { measure in counteracting ship-source } \\
\text { pollution in Hong Kong. }\end{array}$ & $\begin{array}{l}\text { Involved data collection, which was } \\
\text { performed by conducting a } \\
\text { questionnaire survey of selected ship- } \\
\text { ping. }\end{array}$ & $\begin{array}{l}\text { Findings provide useful evidence, } \\
\text { and enable meaningful reflections } \\
\text { on the existing legal and policy } \\
\text { framework covering ship-source } \\
\text { pollution. }\end{array}$ \\
\hline $\begin{array}{l}\text { Özdemir et al. } \\
(2016)\end{array}$ & $\begin{array}{l}\text { To investigate reasons of marine pollution } \\
\text { caused by ship operations and to find } \\
\text { measures to prevent them. }\end{array}$ & $\begin{array}{l}\text { The decision-making trial and } \\
\text { evaluation laboratory method } \\
\text { approach was applied. }\end{array}$ & $\begin{array}{l}\text { The results showed that bunker } \\
\text { oils and bilge waters is a key value } \\
\text { factor and powerful influential } \\
\text { criteria. }\end{array}$ \\
\hline $\begin{array}{l}\text { Onwuegbuchunam } \\
\text { et al. (2017) }\end{array}$ & $\begin{array}{l}\text { To conduct a physico-chemical and } \\
\text { microbiological analysis of samples of } \\
\text { ships' wastewater to determine the status } \\
\text { of marine pollution in the port environ- } \\
\text { ment. }\end{array}$ & $\begin{array}{l}\text { Taking samples from selected areas } \\
\text { and processed at the laboratory and } \\
\text { determination of the physico-chemical } \\
\text { and microbiological parameters. }\end{array}$ & $\begin{array}{l}\text { Results of the laboratory analysis } \\
\text { of the physico-chemical and } \\
\text { microbiological properties of ship } \\
\text { generated wastewater are } \\
\text { presented as bilge, ballast and } \\
\text { black water }\end{array}$ \\
\hline Zhang et al. (2018) & $\begin{array}{l}\text { To propose an innovative risk-based } \\
\text { model for quantitative regional emer- } \\
\text { gency resource allocation, which compre- } \\
\text { hensively analysis the factors such as oil } \\
\text { spill probability, hazard consequences, oil } \\
\text { properties, weathering process and opera- } \\
\text { tion efficiency. }\end{array}$ & The oil spill risk index modelling. & $\begin{array}{l}\text { Results indicate that the } \\
\text { emergency resource allocation } \\
\text { method based on risk assessment is } \\
\text { applicable to the oil spill risk } \\
\text { assessment and capacity building } \\
\text { in the port area. }\end{array}$ \\
\hline Ringbom (2018) & $\begin{array}{l}\text { To explore governance structures in } \\
\text { shipping with a particular focus on the } \\
\text { regulation of environmental protection in } \\
\text { the Baltic Sea. }\end{array}$ & Literature review. & $\begin{array}{l}\text { If the air emission standards are } \\
\text { applied, environmental regulation } \\
\text { of shipping may become more } \\
\text { multi-faceted and dynamic. }\end{array}$ \\
\hline $\begin{array}{l}\text { Jonson et al. } \\
(2020)\end{array}$ & $\begin{array}{l}\text { To find the effects of perturbing ship } \\
\text { emissions by performing a series of } \\
\text { scenario calculations in both globally and } \\
\text { individual sea areas. }\end{array}$ & Scenario based study. & $\begin{array}{l}\text { The impact of ship emissions on } \\
\text { ozone in nearby land areas was } \\
\text { comparable for the some models } \\
\text { but lower for the a model. }\end{array}$ \\
\hline
\end{tabular}




\section{Marine Pollution Caused by Pollutants Other than Oil and Fuel}

Considering the issue of marine pollution, it is seen that there are two main pollutants. The first of these is terrestrial pollutants that have a large share of $80 \%$ in the pollution of the marine environment. The second pollutant that causes the pollution of the seas is marine vehicles, namely ships (Baykal and Baykal, 1999). Maritime transportation activities play an important role in the pollution of the marine environment. Some of the pollution caused by ships arises due to the routine operation of ships (Tütüncü, 2004). This pollution occurs as a result of the ships being discharged into the sea while sailing, such as cargo residues, ballast, sewage, and garbage without complying with the international rules on waste management (Fitoz, 2009; Çevik, 2004).

\section{Cargo Residues}

One of the causes of marine pollution from ships is the discharge of cargo residues into the sea (Çevik, 2004). Cargo residues resulting from the normal activities of the ships consist of the remaining parts of the cargo remaining in the cargo holds of the ship after the discharge and hold-cleaning operations of the ships are completed (URL-2). Within the scope of MARPOL Annex V, rules have been introduced on how cargo residues defined as Harmful to the Marine Environment (HME) can be disposed of. In this context, due to the difficulties experienced by shipowners and operators in finding suitable waste reception facilities at the cargo receiving terminals, it ensures that the washing water of the holds containing solid bulk cargoes that are classified as HME may be discharged outside the special areas under the conditions defined in the circular. It is therefore strongly recommended that shipowners and crew comply with the relevant MARPOL Annex V Rule 4.1.3 and Rule 6.1.2 for the discharge of HME waste (URL-3).

\section{Ballast Water}

The ballast system is a tank system in the bow or sides of the ships where seawater is stored in order to ensure the stability of the ship (Alpay, 2015). Some of the sea creatures in the ballast waters transported by ships die due to temperature changes in the ballast water, food shortage and lightless environment. The surviving creatures are mixed with the new marine ecology they come to when the ballast waters are discharged into the sea. This mixing hinders the functioning of the food chain, damaging the ecology. Invasive species carried by ballast water pose a significant threat to biodiversity. This threat is combined with marine pollution originating from land and excessive use of marine resources, causing changes in the marine habitat (Körpe, 2009).

\section{Sewage}

In accordance with Annex IV of MARPOL, "sewage means drainage and other wastes from any form of toilets, urinals, and WC scuppers; drainage from medical premises (dispensary, sick bay, etc.) via wash basins, wash tubs and scuppers located in such premises; drainage from spaces containing living animals; or other waste waters when mixed with the drainages defined above". In other words, it is the wastewater that occurs as a result of the use of sinks, toilets, showers and kitchens in the ship for seafarers to survive. Among these waters, toilet water is the one with the highest degree of pollution compared to other water and is called black water. Other water, including water from kitchens, is less pollutant than toilet water and is called gray water. While black waters contain too much organic matter, suspended solids, nitrogen, phosphorus and coliform, the coliform content of gray waters is insignificant compared to black water. Discharging sewage into shallow areas with less water circulation causes an increase in eutrophication. The suspended solid material collapses to the bottom of the sea and threatens the natural environment there (Baykal and Baykal, 1999).

\section{Garbage}

MARPOL 73/78, which is the international convention for the prevention of pollution of the seas by ships, contains the rules on preventing the pollution of the seas with the garbage from the ships in Annex V. In this context, garbage includes all kinds of food and operational wastes that need to be disposed of regularly and collected during the normal operation of the ship, except those defined or listed in other Annexes. It is prohibited to discharge any kind of a solid waste to the sea, except food residues that can be discharged 12 miles from the shore from ships. The Mediterranean, the Red Sea, the Baltic Sea, the Black Sea, and the Gulf are designated as special areas within the scope of the Annex, and the discharge of wastes in the sea is prohibited here. The discharge of garbage outside of private areas is mainly subject to the following conditions: Discharging of all kinds of plastic materials into the sea, including synthetic ropes, fishing nets, plastic garbage bags, is prohibited. Certain materials may be discharged into the sea as far as possible from the nearest land, and if the distance to the nearest land is less than specified, discharging into the sea will be prohibited: 25 nautical miles for floating stacking equipment, coatings, and packaging materials; food waste, paper, and cardboard products, glass, rags, and other mineral waste and the like can be dumped up to 12 nautical miles away; food wastes, paper products, glass, rags, and other mineral wastes and the like can be discharged into the sea, not less than 3 nautical miles from the nearest land after they are processed in a shredder and grinder. The pores of 
such crushed and ground garbage are $25 \mathrm{~mm}$. It must be divided into small pieces that are no bigger than the size of the filter (Palabıyık, 2002).

\section{Marine Pollution Caused by Oil and Fuel}

It is the marine pollution caused by discharging sludge, oil, and fuel leaks in the bilge of ships' engine rooms, fuel tanks, or cargo tanks of oil tankers into the sea. The most important of these is the waste accumulated in bilge, sludge and slop tanks.

\section{Bilge Waters}

Leaks consisting of fuel, oil, and cooling water used in all machinery operated with the fuel in the ships accumulate in the bilge located at the bottom of the ship (Fitoz, 2009). The waters collected in the bilge and containing high amounts of oil are called bilge waters. The amount of bilge water in a ship depends on the age, tonnage, and maintenance of the ship (Küçükşahin, 1997). The water accumulated in the bilge must be removed from the ship after a certain period. Otherwise, it will cause corrosion on the ship. If bilge water accumulates and is not discharged, it may cause the cargo to become wet and damp on the loaded ship. If the bilge water in the engine and boiler room is not discharged, it may prevent the normal operation of the machines and seafarers (Küçükşahin, 1997).

\section{Oily Sludge}

Refers to sludge formed from sludge and/or oil sediments in engine rooms of ships, fuel tanks, or cargo tanks of oil tankers (Y1lmaz et al., 2009). According to the Water Pollution Control Regulation, the unused residue remaining from the fuel and oil used by the machines on the ships is called sludge. The unwanted substances contained in the used fuel of the ship's machinery must be purified before use. After the treatment process is over, the residual material, sludge, comes out from the fuel. When the ship arrives at the port, if sludge removal service is not provided within the port service, the ships discharge the sludge to the sea. Since sludge remains on the sea surface for a long time without dispersing, they drag to the beach after a while and take the appearance of pitch sticking to people's feet while walking on the beach (Alpay, 2015)

\section{Tank Washing Water (Slop)}

In the Regulation of Waste Collection from Ships and Control of Wastes, slop is defined as "oily water residues formed as a result of washing the cargo tanks on the ships and accumulated in the tanks" (URL-4). Like bilge waters, tank wash water contains a high percentage of oil, so it poses as much danger to the seas as bilge waters (Gündoğdu, 2013). When the ships carrying oil and petroleum products unload their cargo, some product remains in the tank. When it comes to placing a different cargo in the same tank, the tank is first washed with seawater in order not to spoil the content and purity of the cargo. The mixture of oil and seawater formed as a result of washing is called slop (Fitoz, 2009). It was determined that the remaining cargo in the tanks is $0.35 \%$ of the total cargo (Egemen, 1999). Considering that a tanker carries thousands of tons of oil, this rate is no small amount. According to a study, it was found that as a result of the slop being discharged at sea, approximately 8 to 20 million barrels of oil were thrown into the sea per year (Egemen, 1999).

\section{Air Pollution Caused by Routine Operations of Ships}

The main engines, boilers, and generators in ships are the biggest air pollutants that cause ship-borne exhaust gas emissions in air pollution (Uçar, 2014). Since most of the ships use oil, the oil released into the air from the funnels of these ships causes pollution of the marine environment (Tütüncü, 2004). With the burning of fossil fuels used in ship machinery, harmful exhaust emissions occur in terms of environment and human health. The most important of these emissions are sulphur oxide $\left(\mathrm{SO}_{\mathrm{x}}\right)$, nitrogen oxide $\left(\mathrm{NO}_{\mathrm{x}}\right)$, particulate matter $(\mathrm{PM})$, carbon dioxide $\left(\mathrm{CO}_{2}\right)$, carbon monoxide $(\mathrm{CO})$, polycyclic aromatic hydrocarbons (PAH), and volatile organic compounds (VOC) (Solmaz et al., 2019; Bailey et al., 2004). Air pollutants and greenhouse gases resulting from ship exhaust emissions cause reduced air quality, global warming, and acid rain (Aygül and Baştuğ, 2020). In the study, Nitrogen Oxide $\left(\mathrm{NO}_{\mathrm{x}}\right)$, Sulphur Oxide $\left(\mathrm{SO}_{\mathrm{x}}\right)$, and Particulate Matter $(\mathrm{PM})$, which cause the most air pollution, were discussed.

\section{Nitrogen Oxide (NO $)_{x}$}

Nitrogen oxides are a family of chemicals, including nitric acid, nitrogen dioxide, nitrous oxide, and other related compounds (Bailey et al., 2004). The high temperature that occurs during the combustion in diesel machines is the reason for the formation of nitrogen oxides. The formation of $\mathrm{NO}_{\mathrm{x}}$, which is not only dependent on temperature, occurs depending on the cylinder pressure, air-fuel ratio, combustion time within the cylinder, and the speed of chemical reactions (Şenol, 2020). With the combustion of the fuels used in ships in diesel engines, the temperature in the cylinders reaches $1500^{\circ} \mathrm{C}$ and above. At this temperature, nitrogen and oxygen in the combustion air in the cylinder undergo a chemical reaction and cause $\mathrm{NO}_{\mathrm{x}}$ to be formed (Saraçoğlu, 2010). Since nitrogen oxides cause acid rain by forming nitric acid, it is one of the main emissions to be considered (Şenol, 2020). 5\% of the $\mathrm{NO}_{\mathrm{x}}$ emitted to the atmosphere from the funnels of the ship is $\mathrm{NO}_{2}$ and the rest is nitrogen monoxide. The average residence time in the atmosphere is about one day (Saraçoğlu, 2010). 


\section{Sulphur Oxide (SO $)_{x}$}

Among the sulphur oxides, the most contaminant is $\mathrm{SO}_{2}$ gas, which is colorless, odorless, and soluble in water (Bayat, 2011). $\mathrm{SO}_{2}$ gas is a non-flammable poisonous gas released as a result of burning fossil fuels with high carbon content such as oil, coal, and natural gas (Soysal and Demiral, 2007). The high sulphur content of fossil fuels used in ships has made ships an important source of sulphur dioxide emission in global air pollution (Aygül and Baştuğ, 2020). Certain restrictions have been placed by IMO on sulphur oxide emissions and serious attention has been paid to monitoring ship emissions. IMO has determined the sulphur content in the fuel used by ships as $0.5 \%$ for the areas outside the Emission Control Areas (ECA) to control emissions. In the ECA region, it should be less than $0.1 \%$ (IMO, 2020b).

\section{Particulate Matter (PM)}

Particulate matter (PM) contamination ranges from coarse dust ejected from dirt roads to small sooty particles created when burning wood, gasoline or diesel (Bailey et al., 2004). PM is particles suspended in the air and is a mixture of solid particles and liquid droplets (Aygül and Baştuğ, 2020). And also, it is unburned powdered substances leftover from the reaction and combustion of fossil fuels and lubricating oils used in ships and heavy industries. The size of the particulate matter is in the range of $0.002 \mu \mathrm{m}-500 \mu \mathrm{m}$. PM has many damages to the environment such as corrosion, pollution, and damage to the vegetation. An emission limit of $50 \mu \mathrm{g} / \mathrm{m} 3$ has been determined for ship-sourced PM emissions (Ekmekçioğlu, 2020).

\section{Material and Methods}

\section{Analytical Hierarchy Process (AHP)}

AHP was developed by Thomas Saaty in the 1970s (Şengül et al., 2012). It was first used in probability planning problems in the US Department of Defense in 1971 (Göksu and Güngör, 2008). With AHP, which is based on pairwise comparisons inherent in human nature, the importance and degree of preference of options and criteria are evaluated (Alp and Gündoğdu, 2012).

AHP is a basic approach to decision making. AHP uses both objective and subjective evaluation criteria. It then tests the consistency of the evaluations. It ensures that a very important decision, such as which one should be given priority among the alternatives that should be evaluated according to many criteria, is implemented by the decision-maker. AHP can be defined as a method of expressing the components and variables of a complex and not well-structured situation in a hierarchical order, assigning quantitative values to personal judgments regarding the comparative significance levels of each alternative, and making a synthesis by revealing the priority levels of the variables according to the results of the judgments. Facility location selection, personnel evaluation, evaluation of companies, training evaluation and selection, software selection, target market selection, tourism center selection, and new product development can be given as examples to the studies conducted with the AHP method (Alp and Gündoğdu, 2012). Many solution techniques have been developed for such problems solved under the name of MultiCriteria Decision Making Techniques. AHP is the most used of these techniques. AHP is an effective analysis in multi-criteria decision making (Şengül et al., 2012).

In the first step in AHP, in line with the specified purpose, the criteria and sub-criteria of those criteria are defined and a hierarchical structure is created by the decision-maker In the second step of AHP, by comparing the criteria in pairs, decision-makers are given the opportunity to determine their importance and make the best decision as a result. Complex decisions are synthesized using the AHP method, and both quantitative and qualitative aspects of the decision are revealed (Güngör and İşler, 2005). The following steps are performed in order to solve the decision-making problems with AHP (Alp and Gündoğdu, 2012);

- Creating a hierarchical structure (decomposition),

- Comparative structures and pairwise comparisons,

- Calculation of relative priorities (synthesis),

- Calculation of the consistency ratio.

When there are $\mathrm{n}$ criteria for the specified purpose, a square matrix of size nxn is created. In the created matrix, there are values that show how important i row elements are compared to $\mathrm{j}$ column elements. These given values are evaluated with the Thomas Saaty scale, which indicates the importance levels between the numbers 1-9 in Table 2. As shown in the Criteria Table 3, a pairwise comparison matrix is created (Güngör and İşler, 2005).

Table 2. Saaty AHP Scale.

\begin{tabular}{lc}
\hline Importance level & Definition \\
\hline 1 & equally important \\
3 & a little bit important \\
5 & Important \\
7 & very important \\
9 & absolutely important \\
$2,4,6,8$ & intermediate values \\
\hline
\end{tabular}

Source: Saaty, T. L. (1980).

If the hierarchy contains $n$ criteria, a total of $n(n-1) / 2$ pairwise comparisons are required. The pairwise comparisons 
matrix contains the values of $w i / w j$. The expression $w i / w j$ expresses how important the $i$ criterion is than the $j$ criterion (Şengül et al., 2012).

Table 3. Creating a Pairwise Comparison Matrix for Criteria

\begin{tabular}{lcc}
\hline & Criterion 1 & Criterion 2 \\
\hline Criterion 1 & $\mathrm{~W} 1 / \mathrm{W} 1$ & $\mathrm{~W} 1 / \mathrm{W} 2$ \\
Criterion 2 & $\mathrm{~W} 2 / \mathrm{W} 1$ & $\mathrm{~W} 2 / \mathrm{W} 2$ \\
Criterion $\mathrm{n}$ & $\mathrm{Wn} / \mathrm{W} 1$ & $\mathrm{Wn} / \mathrm{W} 2$ \\
\hline
\end{tabular}

Source: Vargas L.G. (1990).

The next step after the creation of paired comparison matrices is to calculate the eigenvector that shows the importance of each item in the relevant matrix compared to other items (Sipahioğlu, 2008). The $n x 1$ dimension eigenvector of the matrix is determined as follows (Supçiller and Capraz, 2011).

$i=1,2,3, \ldots \ldots, \mathrm{n}$ ve $j=1,2,3, \ldots, \mathrm{n}$

$b_{i j}=\frac{a_{i j}}{\sum_{i=1}^{n} a i j}$

$w_{i}=\frac{\sum_{j=1}^{n} b_{i j}}{n}$

Matrix consistency is calculated by finding the relative importance of the criteria. For a comparison matrix to be consistent, its largest eigenvalue ( $\lambda \max )$ must be equal to the matrix size (n). To calculate the relative importance of the criteria, the column vector "wi" is constructed by taking the geometric mean of each row. By normalizing the created column vector, the relative importance vector "Wi" is calculated. By multiplying each row in the matrix by the relative importance vector, the column vector V2 is calculated. Then, the vector $\mathrm{V} 3$ is calculated by dividing each element of this vector by the corresponding element in the relative importance vector, and the arithmetic mean of the column vector $\mathrm{V} 3$ gives the largest eigenvalue $\lambda \max$ (Güngör and İşler, 2005).

$C I=\frac{\kappa_{\max }-n}{n-1}$

$\lambda_{\max }=\frac{\sum_{i=1}^{n} \frac{d i}{w i}}{n}$

$C R=\frac{C I}{R I}$
The Consistency Ratio (CR) is obtained by dividing the Consistency Indicator (CI) value by the Random Consistency Index (RI) value shown in Table 4. The randomness indicator is calculated for 15-dimensional matrices at most. The high number of criteria reduces the possibility of obtaining consistent results when all criteria are evaluated together (Güngör and İşler, 2005).

\section{Application}

In the study, it is aimed to determine which pollutants cause the most damage within the scope of marine and air pollution caused by the routine operation of ships. First, a questionnaire form was prepared in which pairwise comparisons of the criteria determined by the literature review were made. This questionnaire was applied to 6 experts working as decisionmakers, such as technical managers, or DPAs. Two of these experts work as technical managers and others as DPA. Technical managers are qualified as chief engineers and DPAs are qualified as captains. In addition, the duration of each expert's work onboard is over 15 years. These 6 experts were asked to compare the marine and air pollution criteria due to the routine operations of the ships and the sub-criteria of these criteria. The hierarchical structure of the criteria is given in Figure 1. Microsoft Excel program was used to solve these comparisons.

\section{Pairwise Comparison of Main Criteria}

The data in Table 5 was created by taking the geometric mean of the results in the survey evaluated by experts' opinions of the main criteria. Evaluation of the main criteria is shown in Table 5.

The weights of the data in Table 5, i.e. their degrees of importance, are calculated and shown in Table 6. Considering the weight of the main criteria, it is thought that marine pollution caused by oil and fuel causes more damage to the environment than marine pollution caused by pollutants other than oil and fuel and air pollution. It is observed that the marine pollution caused by pollutants other than oil and fuel causes the least damage. And also, the calculated consistency ratio value is 0.02 , since $\mathrm{CR}=0.02<0.10$, the comparisons were found to be consistent.

Table 4. Random Consistency Index (RI)

\begin{tabular}{cccccccccccccccc}
\hline $\mathrm{N}$ & 1 & 2 & 3 & 4 & 5 & 6 & 7 & 8 & 9 & 10 & 11 & 12 & 13 & 14 & 15 \\
\hline $\mathrm{RI}$ & 0 & 0 & 0.58 & 0.9 & 1.12 & 1.24 & 1.32 & 1.41 & 1.45 & 1.49 & 1.51 & 1.48 & 1.56 & 1.57 & 1.59 \\
\hline
\end{tabular}

Source: Güngör and İşler, (2005)

If the Consistency Ratio (CI) obtained is less than 0.10, the matrix created is consistent (Şengül et al., 2012) 


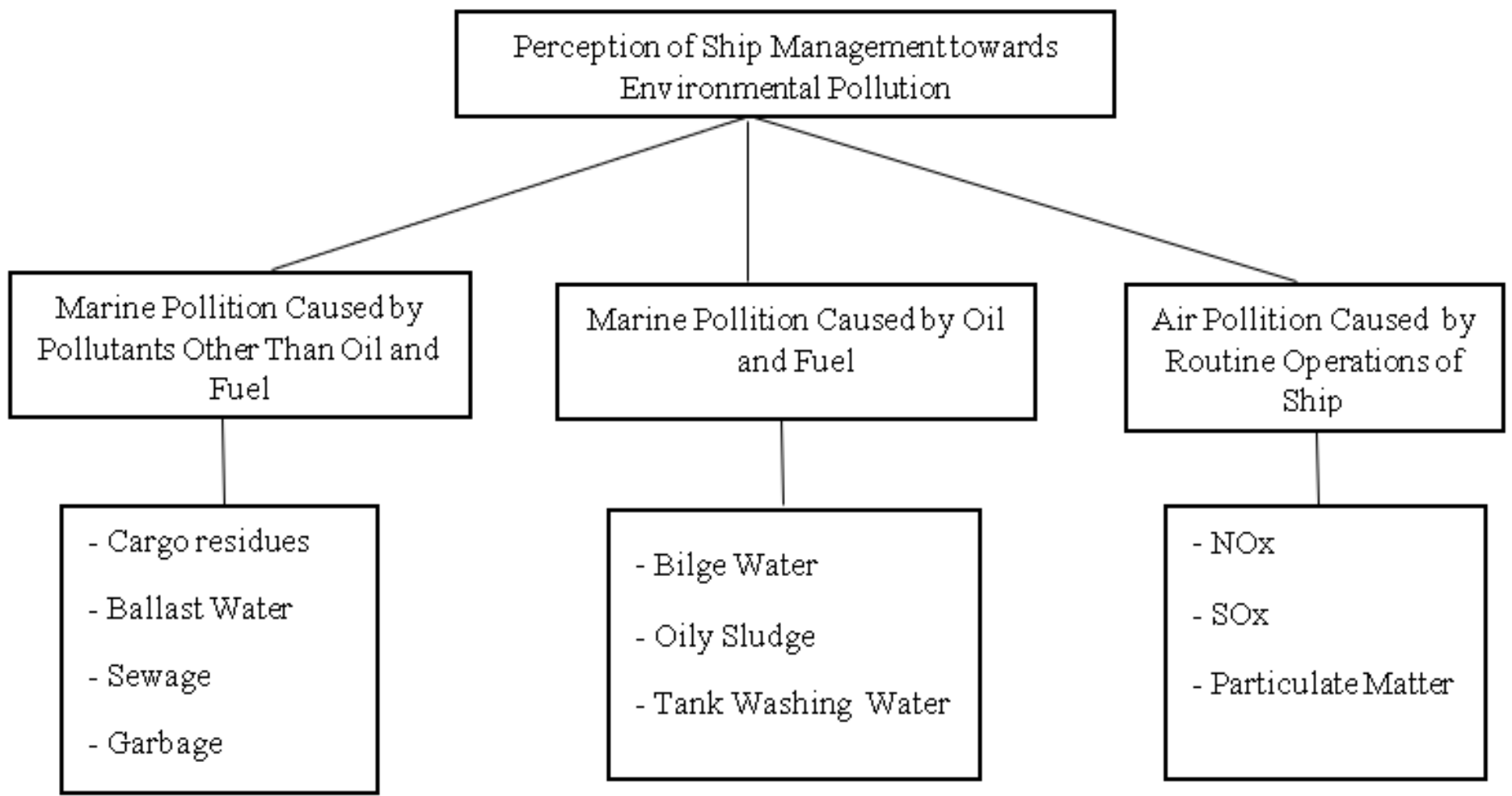

Figure 1. The hierarchical structure of the criteria.

Table 5. Pairwise Comparison of Main Criteria

\section{Criteria}

Marine Pollution Caused by Pollutants Other Than Oil and Fuel

Marine Pollution Caused by Oil and Fuel

Air Pollution Caused by Routine Operations of Ships
Marine Pollution Caused by Pollutants Other Than Oil and Fuel
Marine Pollution Caused by Oil and Fuel
Air Pollution Caused by Routine Operations of Ships

$\begin{array}{ccc}1 & 0.166 & 0.411 \\ 6.008 & 1 & 5.581 \\ 2.430 & 0.179 & 1\end{array}$

\begin{tabular}{lc}
\hline Table 6. Weights of Main Criteria & Weights \\
\hline \multicolumn{1}{c}{ Criteria } & 0.081 \\
\hline Marine Pollution Caused by Pollutants Other Than Oil and Fuel & 0.696 \\
Marine Pollution Caused by Oil and Fuel & 0.222 \\
Air Pollution Caused by Routine Operations of Ships & \\
Consistency Ratio (CR): 0.02 & \\
\hline
\end{tabular}




\section{Pairwise Comparison of Sub-Criteria for Marine Pollution Caused by Pollutants Other than Oil and Fuel}

Sub-criteria of marine pollution caused by pollutants other than oil and fuel were compared by experts. The group decision was calculated after the geometric mean of the data obtained by preparing the paired comparison matrix in Table 7 .

Considering the weights in Table 8, the ballast water sub-criterion was evaluated as the most damaging pollutant to the environment by experts' opinions. Sewage, on the other hand, is the least harmful pollutant. Since the Consistency Ratio $=$ $0.019<0.10$, the pairwise comparison matrix was found to be consistent.

\section{Pairwise Comparison of Sub-Criteria for Marine Pollution Caused by Oil and Fuel}

Sub-criteria of marine pollution caused by oil and fuel were compared by experts. The group decision was calculated after the geometric mean of the data obtained by preparing the paired comparison matrix in Table 9.
Considering the weights in Table 10, the bilge waters subcriterion was evaluated as the most damaging pollutant to the environment by experts' opinions. Tank Washing Water (Slop), on the other hand, is the least harmful pollutant. Since the Consistency Ratio $=0.021<0.10$, the pairwise comparison matrix was found to be consistent.

\section{Pairwise Comparison of Sub-Criteria for Air Pollution Caused by Routine Operations of Ships}

Sub-criteria of air pollution resulting from the routine operations of ships were compared by experts. The group decision was calculated after the geometric mean of the data obtained by preparing the paired comparison matrix in Table 11 .

Considering the weights in Table 12, Sulphur Oxide $\left(\mathrm{SO}_{\mathrm{x}}\right)$ sub-criterion was evaluated as the most damaging pollutant to the environment by experts' opinions. Nitrogen Oxide $\left(\mathrm{NO}_{\mathrm{x}}\right)$, on the other hand, is the least harmful pollutant. Since the Consistency Ratio $=0.073<0.10$, the pairwise comparison matrix was found to be consistent.

Table 7. Pairwise comparison of sub-criteria of marine pollution caused by pollutants other than oil and fuel

\begin{tabular}{lcccc}
\hline Criteria & Cargo residues & Ballast water & Sewage & Garbage \\
\hline Cargo residues & 1 & 0.350 & 3.992 & 0.321 \\
Ballast water & 2.853 & 1 & 3.360 & 2.078 \\
Sewage & 0.250 & 0.297 & 1 & 0.303 \\
Garbage & 3.107 & 0.481 & 3.295 & 1 \\
\hline
\end{tabular}

Table 8. The weights of sub-criteria of marine pollution caused by pollutants other than oil and fuel

\begin{tabular}{lc}
\hline Criteria & Weights \\
\hline Cargo residues & 0.180 \\
Ballast water & 0.488 \\
Sewage & 0.082 \\
Garbage & 0.249 \\
Consistency Ratio (CR): 0.019 & \\
\hline
\end{tabular}

\begin{tabular}{lccc}
\hline \multicolumn{4}{l}{ Table 9. Pairwise comparison of sub-criteria of marine pollution caused by oil and fuel } \\
\hline Criteria & Bilge Waters & Oily Sludge & Tank Washing Water \\
\hline Bilge Waters & 1 & 6.265 & 5.273 \\
Oily Sludge & 0.159 & 1 & 1.348 \\
Tank Washing Water & 0.189 & 0.741 & 1 \\
\hline
\end{tabular}

Table 10. The weights of sub-criteria of marine pollution caused by oil and fuel

\begin{tabular}{lc}
\hline Criteria & Weights \\
\hline Bilge Waters & 0.738 \\
Oily Sludge & 0.140 \\
Tank Washing Water (Slop) & 0.121 \\
Consistency Ratio (CR): 0.021 & \\
\hline
\end{tabular}


Table 11. Pairwise comparison of sub-criteria of air pollution resulting from the routine operations of ships

\begin{tabular}{lccc}
\hline Criteria & Nitrogen Oxide $\left(\mathrm{NO}_{\mathrm{x}}\right)$ & Sulphur Oxide $\left(\mathrm{SO}_{\mathrm{x}}\right)$ & Particulate Matter $(\mathrm{PM})$ \\
\hline Nitrogen Oxide $\left(\mathrm{NO}_{\mathrm{x}}\right)$ & 1 & 0.278 & 0.458 \\
Sulphur Oxide $\left(\mathrm{SO}_{\mathrm{x}}\right)$ & 3.595 & 1 & 3.914 \\
Particulate Matter $(\mathrm{PM})$ & 2.182 & 0.255 & 1 \\
\hline
\end{tabular}

Table 12. The weights of sub-criteria of air pollution resulting from the routine operations of ships

\begin{tabular}{lc}
\hline Criteria & Weights \\
\hline Nitrogen Oxide $\left(\mathrm{NO}_{\mathrm{x}}\right)$ & 0.138 \\
Sulphur Oxide $\left(\mathrm{SO}_{\mathrm{x}}\right)$ & 0.637 \\
Particulate Matter $(\mathrm{PM})$ & 0.224 \\
Consistency Ratio (CR): 0.073 & \\
\hline
\end{tabular}

\section{Results and Discussion}

Three main criteria and their sub-criteria were prioritized by experts using the AHP method. The weights written in bold color in Table 13 are criteria that have the highest weight resolved according to the data obtained from experts.

As seen in Table 13, when the main criteria that cause environmental pollution caused by the routine operations of ships are listed by weight, it is seen that marine pollution caused by oil and fuel comes first, and then air pollution and marine pollution caused by pollutants other than oil and fuel, respectively. As can be seen from the weights, oil and fuel pollution has emerged as the most damaging pollutant to the environment. It is observed that the damage caused by the discharge of the bilge waters of the ships into the sea is the most. The bilge water, which consists of fuel, oil, and cooling water used in the machines, causes corrosion and wetting of the load and creates a negative effect on the ship. Discharge of bilge waters into the sea without complying with international rules plays a significant role in marine pollution.

Table 13. The weights of criteria of environmental pollution caused by routine operations of ships

\begin{tabular}{lclc}
\hline Criteria & Weights of Criteria & Sub-criteria & Weights of Sub-Criteria \\
\hline \multirow{2}{*}{$\begin{array}{l}\text { Marine Pollution Caused by Pollu- } \\
\text { tants Other Than Oil and Fuel }\end{array}$} & \multirow{2}{*}{0.081} & Cargo residues & 0.180 \\
& & Ballast water & $\mathbf{0 . 4 8 8}$ \\
& & Sewage & 0.082 \\
Marine Pollution Caused by Oil & Garbage & 0.249 \\
\cline { 3 - 4 } and Fuel & \multirow{2}{*}{$\mathbf{0 . 6 9 6}$} & Bilge Waters & $\mathbf{0 . 7 3 8}$ \\
& & Oily Sludge & 0.140 \\
Air Pollution Caused by & Tank Washing Water (Slop) & 0.121 \\
Routine Operations of Ships & \multirow{2}{*}{0.222} & Nitrogen Oxide (NOx) & 0.138 \\
& & Sulphur Oxide (SOx) & $\mathbf{0 . 6 3 7}$ \\
\hline
\end{tabular}


Air pollution caused by the routine operations of ships ranks second. It is thought that the damage caused by sulphur oxide to the environment is more in emission emissions. As a result of the burning of fossil fuels in ship engines, a lot of sulphur oxide gas is mixed into the atmosphere. The release of sulphur oxide causes problems such as ozone depletion, acid rain, and respiratory distress in humans.

Marine pollution caused by pollutants other than oil and fuel is thought to be the least. Among the sub-criteria, it was observed that ballast water ranks first among pollutants. As a result of the ballast operation, sea creatures carried by ballast water can be included in a different marine ecology and harm the living creatures there.

\section{Conclusion}

In the study, environmental pollution caused by the routine operations of the ships has been discussed. In this context, practices in routine operations of ships that cause environmental pollution are listed based on expert opinions according to their damage to the environment. Thus, the perception of ship operators about environmental pollution has been revealed. The main and sub-criteria formed as a result of the literature review were presented to the expert group with a questionnaire and they were asked to compare these criteria and sub-criteria. In the study, the AHP technique, which is the most used method among Multi-Criteria Decision-Making Techniques and an effective method in paired comparisons, was used. According to the priorities obtained as a result of the calculations specific to AHP, it is seen that the damage to the environment by Marine Pollution Caused by Oil and Fuel is in the first place. The second is Air Pollution Caused by Routine Operations of Ships. Marine Pollution Caused by Pollutants Other Than Oil and Fuel is thought to pollute the environment the least.

In marine pollution, it is seen that the pollution caused by oil and fuel wastes such as bilge, slop, and sludge in the seas comes to the fore. It is a necessity for these pollutants to be delivered to waste reception facilities in ports or to be discharged to the seas in accordance with international rules, to protect the marine environment. In addition, according to MARPOL 73/78, ships must store on board wastes that are not allowed to be discharged into the sea. However, in order to fulfill this, the number of waste reception facilities in ports should be increased. Another issue that should be considered is the necessity of operating the existing treatment systems in ships in accordance with IMO standards.

Regarding emissions, which rank second, the use of high sulphur fuels comes first in ship-borne air pollution. To prevent this IMO has introduced restrictions on sulphur emissions.
With the decision of IMO, the sulphur rate in the fuels of ships sailing outside the ECA region in 2020 was reduced from $3.5 \%$ to $0.5 \%$. For this purpose, ship operators are expected to use low-sulphur fuel, to turn to renewable energy sources, or to exhibit more environmentally friendly ship management by taking advantage of chimney filtering systems such as scrubber.

Within the scope of marine pollution caused by pollutants other than oil and fuel, it is seen that ballast operations are in the first place because they are carried out without complying with the rules and thus negatively affect the marine ecology. In this context, it is considered important to equip ships with ballast water management systems within the scope of The International Convention for the Control and Management of Ships' Ballast Water and Sediments, which was put forward by IMO in 2004 and entered into force in 2017.

As a result, by applying an environmentally sensitive management policy of ship operators, it will be important to raise the awareness of ship personnel about environmental pollutants and their damage to the environment, to improve marine pollution prevention training, and to eliminate operational defects in preventing marine pollution.

\section{Compliance with Ethical Standard}

Conflict of interests: The authors declare that for this article they have no actual, potential or perceived conflict of interests.

Ethics committee approval: Ethics committee approval is not required.

\section{Funding disclosure: -}

Acknowledgments: -

Disclosure: -

\section{References}

Alp, S., Gündoğdu, C.E. (2012). Analytical hierarchy process and fuzzy analytical hierarchy process application in choosing the place of incorporation. Dokuz Eylül University the Journal of Graduate School of Social Sciences, 14(1), 0725 .

Alpay, C.G. (2015). The Evaluation of Studies on The Prevention of The Marine Pollution Within The Metropolitan Municipalities. Master Thesis, Institute of Science, Istanbul Technical University, Istanbul. 
Aygül, Ö., Baştuğ, S. (2020). maritime transport-based air pollution and its effect on human health. Journal of Maritime Transport and Logistics, 1(1), 26-40.

Bayat, B. (2011). Hava kirliliği ve kontrolü, Bilim ve Aklın Aydınlığında Eğitim Dergisi, 135(1), 55-59.

Bailey, D., Plenys, T., Solomon, G.M., Campbell, T.R., Feurer, G.R., Masters, J., Tonkonogy, B. (2004). Harboring Pollution: The Dirty Truth about U.S. Ports. Natural Resources Defense Council (NRDC).

Baykal, B.B., Baykal, M.A. (1999). Gemi Kaynakl1 Evsel Atık Sular ve Gemilerde Atık Su Yönetimi. A. İ. Aldoğan, Y. Ünsan, E. Bayraktarkatal (Eds.), Gemi İnşaatı ve Deniz Teknolojisi Teknik Kongresi, Bildiri Kitabı, İstanbul,Yapım Matbaacilik.

Çevik, Ü. (2004). Uluslararası Denizcilik Sözleşmeleri. p.250, İstanbul, Birsen Yayınları, ISBN: 975-511-375-4

Egemen, Ö. (1999). Çevre ve Su Kirliliği. Ege Üniversitesi Su Ürünleri Fakültesi Yayınları 3. Baskı, No: 42.

Ekmekçioğlu, A. (2020). Calculation of Ship-Based Emissions by Numerical Methods. Master Thesis, Yıldız Technical University, Institute of Science, Istanbul.

Fitoz, C. (2009). Prevention of Ship-Originated Marine Pollution and Recommendations for the Turkish Straits. Master Thesis, Çanakkale Onsekiz Mart University, Institute of Social Sciences, Çanakkale.

Göksu, A., Güngör, İ. (2008). Bulanık analitik hiyerarşik proses ve üniversite tercih siralamasında uygulanması. Süleyman Demirel Üniversitesi İI. B.F. Dergisi, 13(3), 1-26.

Güngör, İ., İşler, D.B. (2005). Analitik hiyerarşi yaklaşımı ile otomobil seçimi. Zonguldak Karaelmas Üniversitesi Sosyal Bilimler Dergisi, 1(2), 21-33.

Gündoğdu, M. (2013). The investigation of pollution level in ship wastewater. Master Thesis, Frrat University, Institute of Science.

Iduk, U., Nitonye, S. (2015). Effects and solutions of marine pollution from ships in Nigerian waterways. International Journal of Scientific \& Engineering Research, 6(9), 81-90.
IMO (2020a). International Convention for the Prevention of Pollution from Ships (MARPOL). Retrieved from https://www.imo.org/en/About/Conventions/Pages/International-Convention-for-the-Prevention-of-Pollution-from-

Ships-(MARPOL).aspx (accessed 18.09.2020).

IMO (2020b). Sulphur Oxides (SOx) and Particulate Matter (PM)-Regulation 14. Retrieved from

http://www.imo.org/en/OurWork/Environment/Pollution-

Prevention (accessed 25.11.2020).

Jonson, E.J., Gauss, M., Schulz, M., Jalkanen, J.P., Fagerli, H. (2020). Effects of global ship emissions on European air pollution levels. Atmospheric Chemistry and Physic, 20(19), 11399-11422.

https://doi.org/10.5194/acp-20-11399-2020

Körpe, Ö. (2009). Ballast water management. Master Thesis, Istanbul Technical University Institute of Science.

Küçük, Y.T., Topçu, A. (2012). Pollution from maritime transportation. Ankara University Journal of Environmental Sciences, 4(2), 75-79.

https://doi.org/10.1501/Csaum 0000000067

Küçükşahin, F. (1997). Gemi Makineleri. Birsen Yayınevi, İstanbul. ISBN: 9789755115993 MARPOL 73/78.

Retrieved from https://www.marpolandsolas.com (accessed 21.09.2020).

Miola, A., Ciuffo, B. (2011). estimating air emissions from ships: meta-analysis of modelling approaches and available data sources. Atmospheric Environment, 45(13), 2242-2251. https://doi.org/10.1016/i.atmosenv.2011.01.046

Onwuegbuchunam, D.E., Ebe, T. E., Okoroji, L.I., Essien, A.E. (2017). An analysis of ship-source marine pollution in Nigeria seaports. Journal of Marine Science and Enginnering, 5(3), 39.

https://doi.org/10.3390/jmse5030039

Özdemir, Ü., Yılmaz, H., Başar, E. (2016). Investigation of marine pollution caused by ship operations with DEMATEL method. The International Journal on Marine Navigation and Safety of Sea Transportation, 10(2), 315-320.

https://doi.org/10.12716/1001.10.02.14

Palabıyı, H. (2002). Gemi ve Liman Atık Yönetimi ve MARPOL 73/78: İzmir Limanı Örneği. 5-6 Kasım, Türkiye Kıyıları Kongresi, İzmir, ss. 997-1006. 
Potters, G. (2013). Marine Pollution. Bookboon, 1st edition. ISBN 978-87-403-0540-1

Ringbom, H. (2018). Regulation of ship-source pollution in the Baltic Sea. Marine Policy, 98, 246-254.

https://doi.org/10.1016/j.marpol.2018.09.004

Saaty, T.L. (1980). The Analytic Hierarchy Process. USA: McGraw-Hill.

https://doi.org/10.21236/ADA214804

Saraçoğlu, H. (2010). Investigation of exhaust gas emissions of ships calling Izmir Port and their environmental impact. Master Thesis, Istanbul Technical University Institute of Science.

Satır, T. (2007). Developing Port Reception Facility Model in the Turkish Ports for Establish and Management Sufficent for International Convention for the Prevention of Pollution from Ships. Ph.D. Thesis, Istanbul University Institute of Marine Sciences and Management, Istanbul.

Saxe, H., Larsen, T. (2004). Air pollution from ships in three Danish ports. Atmospheric Environment, 38(24), 4057-4067. https://doi.org/10.1016/j.atmosenv.2004.03.055

Sipahioğlu, A. (2008). Analitik Hiyerarşi Süreci (AHP) Ders Notları, Osman Gazi Üniversitesi Endüstri Mühendisliği Bölümü.

Solmaz, M.S., Başkaya A., Savaş A., Akman M. (2019). Utilization of renewable energy in ships: optimization of hybrid system installed in an oil barge with economic and environmental pollution analysis. Journal of ETA Maritime Science, 7(2), 179-191.

https://doi.org/10.5505/jems.2019.30643

Soysal, A., Demiral, Y. (2007). Kapalı ortam hava kirliliği. TSK Koruyucu Hekimlik Bülteni, 6(3), 221-226.

Supçiller, A.A., Çapraz, O. (2011). Ahp-Topsis Yöntemine Dayalı Tedarikçi Seçimi Uygulaması, Ekonometri ve İstatistik, 13(12) Uluslararası Ekonometri, Yöneylem Araştırması, İstatistik Sempozyumu Özel Sayıs1, 1-22.

Şengül, Ü., Eren, M., Eslamian Shıraz, S. (2012). Municipalities Public Transport Vehicle Selection Using Fuzzy Ahp. Erciyes University Journal of Faculty of Economics and Administrative Sciences, 40, 143-165.
Şenol, S. (2020). Gemi kökenli emisyonlara dayalı alternatif sevk sistemleri. GIDB Dergi, 18, 31-56.

Tütüncü, A.N. (2004). Gemi Kaynaklı Deniz Kirlenmesinin Önlenmesi, Azaltılması ve Kontrol Altına Alınmasında Devletin Yetkisi. Beta, İstanbul. ISBN 975-295-362-X

Uçar, O.F. (2014). Samsun İli Limanlarına Gelen Gemilerin Oluşturduğu Egzoz Gazı Emisyonlarının İncelenmesi ve Çevresel Etkileri. Denizcilik Uzmanlık Tezi, T.C. Ulaştırma Denizcilik ve Haberleşme Bakanlığı.

UN Convention on the Law of the Sea (UNCLOS) (1982). (Article 1.4) Retrieved from

https://www.un.org/depts/los/convention agreements/texts/unclos/unclos_e.pdf (accessed 10.02.2021)

URL-1, 8 Ways Cruise Ships Can Cause Marine Pollution, (2020). Retrieved from https://www.marineinsight.com/environment/8-ways-in-which-cruise-ships-can-cause-marinepollution/ (accessed 08.01.2021).

URL-2, Gemilerden Alınan Atık Türleri ve Açıklamaları. Retrieved from https://istac.istanbul/contents/46/gemilerdenatik-alimi_130838442818551895.pdf (accessed 05.12.2020).

URL-3, HME Yük Atıklarının Denize Boşaltımının Yasaklanmas1. Retrieved from https://www.denizticaretodasi.org.tr/tr/haberler/hme-yuk-atiklarinin-denize-bosaltiminin-yasaklanmasi-1018-1 (accessed 05.12.2020).

URL-4, Gemilerden Atık Alinmasi ve Atıkların Kontrolü Yönetmeliği, Resmî Gazete Tarihi: 26.12.2004, Say1s1: 25682, Retrieved from https://www.mevzuat.gov.tr/mevzuat?MevzuatNo=5672\&MevzuatTur=7\&MevzuatTertip $=5$ (accessed 08.01.2021).

Vargas, L.G. (1990). An overview of the analytic hierarchy process and its applications. European Journal of Operational Research, 48(1), 2-8.

https://doi.org/10.1016/0377-2217(90)90056-H

Walker, T.R., Adebambo, O., Del Aguila Feijoo, M.C., Elhaimer, E., Hossain, T., Edwards, S.J., Morrison, C.E., Romo, J., Sharma, N., Taylor, S., Zomorodi, S. (2019). environmental effects of marine transportation. world seas: an Environmental Evaluation (Second Edition), Ecological Issues and Environmental Impacts, 3, 505-530. https://doi.org/10.1016/B978-0-12-805052-1.00030-9 
Yılmaz, E., Yetkin, M., Yıldız, Ş. (2009). Petrol ve Petrol Türevli Gemi Kaynaklı Atıksuların Bertaraf ve Yönetimi: İstanbul Örneği, TÜRKAY Türkiye'de Katı Atık Yönetimi Sempozyumu, YTÜ, İstanbul.

Zhang, C., An, W., Xiong, D. Liu, B., Song, S. (2018). Research on the risk-based model for regional emergency re source allocation for ship-source oil spill. Acta Oceanologica Sinica, 37(11), 133-138.

https://doi.org/10.1007/s13131-018-1253-x

Zhu L., Zhao Y.C., (2015). A feasibility assessment of the application of the polluter-pays principle to ship-source pollution in Hong Kong. Marine Policy, 57, 36-44.

https://doi.org/10.1016/j.marpol.2015.03.010 